\title{
9 The Mössingen Library Emerges from the Pausa Tonnenhalle in Germany
}

\begin{abstract}
A barrel hall, designed in 1950/51 by the architect Manfred Lehmbruck as a textile printing hall for the Pausa company and extended in 1962 into a larger industrial complex was listed as a historical monument after the company went bankrupt in 2004. In 2011, the structure found a new use as the Mössingen public library when the building was renovated and converted in accordance with listed building regulations. The philosophy, and the benefits and challenges of combining a new use with a historic building, are described from the point of view of the architect and of the librarian. The project architect outlines the context informing his strongly held belief in the importance of connecting places and buildings with their history. The solutions that met the requirements of both the new use as a library and the protection and preservation of a listed building are described. The librarian discusses the advantages and disadvantages of the conversion and the library's importance to users.
\end{abstract}

Keywords: Public libraries - Germany; Library buildings - Design and construction; Industrial buildings - Remodelling for other use

\section{Introduction}

The city of Mössingen, in the Tübingen area of southern Germany, has 20,000 inhabitants including those in the surrounding villages. The main public library branch in Mössingen, founded in 1981, moved to the listed Pausa Tonnenhalle in 2011. The industrial building was sensitively renovated in accordance with historic building legislation and converted into the Mössingen public library (Figure 1). The conversion retains clear traces throughout the building of the unique production history of the Pausa fabric printing works.

The area in which the barrel hall is located is known as the Pausa district. The administration building, boiler house and former canteen are located on the site. A café and Streuobst-Erlebniszentrum/Orchards Experience and Information Centre (https://www.moessingen.de/de/Freizeit-Tourismus/Informieren/ Infozentrum-Streuobstparadies) have occupied the former canteen since 2018. The weekly market enlivens the square outside the library. The long ramp (Figure 9) and the elevator enable barrier-free access to the library, and the ramp is often

2 Open Access. (2021 Michael B. Frank and Canan Kadi, published by De Gruyter. (c))BY-NC-ND This work is licensed under the Creative Commons Attribution-NonCommercial-NoDerivatives 4.0 International License. https://doi.org/10.1515/9783110679663-010 
used as a runway for races between children! The library is a place where people meet, learn together, exchange ideas and spend time.

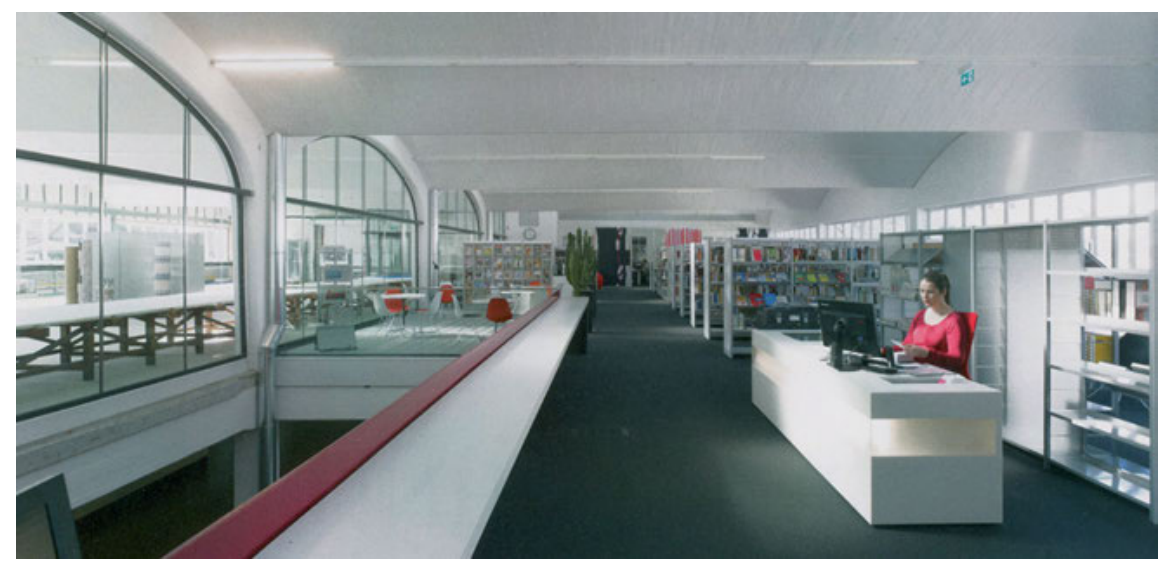

Fig. 1: The high ceilings, the many windows and the barrel-vaulted structure of the Mössingen library offer a very pleasant workplace. (C) Wolfram Janzer.

\section{Facts and Figures}

Name: Stadtbücherei Mössingen

Address: Löwensteinplatz 1, 72116 Mössingen, Germany

Website: https://www.moessingen.de/de/Stadt-Buerger/Bildung-Familie/Stadtbuecherei Opening: January 2011

Builder: Stadt Mössingen

Architect: baldauf architekten gmbh; https://baldaufarchitekten.de/; Design and Project Architect: Michael B. Frank http://www.mb-frank-architektur.de

Gross floor area: $4,500 \mathrm{~m}^{2}$

Main floor space: $810 \mathrm{~m}^{2}$

Collection size: 60,000

Staff: 5

Workstations: 4

Building costs: $€ 11,200,000$ 


\section{The Architect's Philosophy: A Personal Perspective}

A dominating conceptual approach to my work as an architect since the early 1990s, has been a consideration of how history might become an integral part of a project. How can history live on within a project? has been the common question and thread through many projects undertaken over the last thirty years. One of the key German theorists on architectural thinking, Dieter Hoffmann-Axthelm (1987) expressed the challenge in a collection of essays: Wie kommt die Geschichte ins Entwerfen? The ideas expressed made a significant impact on my understanding of architecture as a student in London at the Bartlett School of Architecture at University College London (UCL). Translating the title of the collection into English is almost as problematic as answering the question itself. How does history impact on architectural design? How can architectural design be linked to history? The crucial question has always been uppermost in my thoughts when commencing the design for a specific site.

Although the impact of history on design seems obvious in the context of architecture and urban design, it took me almost twenty years to develop the proposition initially conceptualised during study undertaken at the Bartlett School of Architecture, at the time led by Peter Cook. Peter Cook was one of the members and founders of the famous, or perhaps infamous, avant-garde Archigram group in the 1960s in London. The group drew inspiration from technology and sought to create a new anti-heroic and pro-consumerist reality for the future.

To work with the unseen, with the traces of history and, sometimes, their suppression became a guideline for my design approach and my claim as an architect. The refurbishment of the industrial complex originally built for the Pausa company provided the impetus and opportunity for ensuring that the history of the building would shape its future as a library for Mössingen. The original building was constructed in the 1950s and designed by the architect Manfred Lehmbruck (1913-1992, son of the German sculptor Wilhelm Lehmbruck). The Pausa company was a printing company which established itself worldwide and gained a reputation for exclusive and ambitious textile design.

\section{The Context}

Why and how did Berlin come to the small city of Mössingen and its library in south-west Germany? In 1990/91, I submitted a diploma thesis in the Bartlett School of Architecture entitled SubBerlin: Ein Museum für Deutsche Geschichte 
(SubBerlin: A Museum for German History as a Situationist, Urban Intervention/ Installation in Central Berlin (http://www.mb-frank-architektur.de/referenzen/ architektur/subberlin). The thesis, which has continued to influence my approach to design throughout my career including the work at Pausa, dealt with topics that are usually beyond the realm of architecture and urban planning. The point is made that architectural design can contribute to the identification and interconnectedness of people to place through the deliberate and subtle incorporation of history into future planning. Good design reflects the physical manifestation and the soul of a place and includes all aspects, its wounds, suppressed trauma, love and hate.

\section{The Historical Background}

In Berlin, in 1990, most inhabitants wanted to bury the history of the Deutsche Demokratische Republik/German Democratic Republic (GDR) commonly known as East Germany, and in particular the so-called Todesstreifen/death strip which had divided the city in two. The border between the GDR and the Bundesrepublik Deutschland/Federal Republic of Germany (FDR) commonly known as West Germany, in place between 1949 and 1990 took various forms. Until 1956, the GDR officially designated the border as a demarcation line, then a border and from 1964 a state border; it was also called a death strip. Rather than a critical or conceptual debate about urban design, the overriding imperative after 1990 seemed to be the erasing of history and memory as quickly as possible. Indeed, the Berlin Wall was gone in an amazingly short time and reduced to rubble (Figures 2 and 3)!

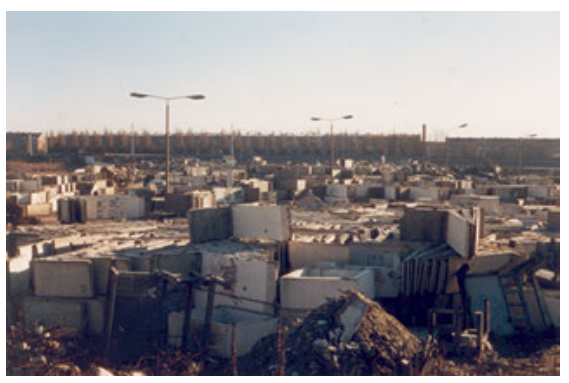

Fig. 2: Wall-graveyard in Berlin-Pankow, January 1991. (C) Michael B. Frank.

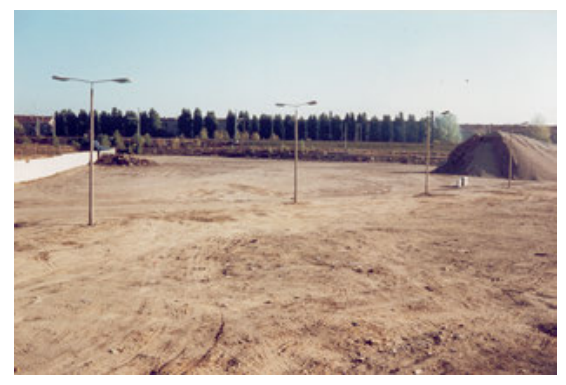

Fig. 3: Wall-graveyard in Berlin-Pankow, July 1991. (C) Michael B. Frank. 
Despite the elimination of many historical reminders, it is not possible to eradicate history from people's minds and hearts. At the historic time of German reunification in 1990, the following crucial questions were rarely asked:

- What connects people to a place?

- What do they identify with?

- What do they hate?

- What do they love?

- What offends them?

Fundamentally, it comes down to the question of the soul or, in a more profane sense, the essential character of a place or city, its genius loci or pervading spirit. The thesis of SubBerlin is:

- Architectural design can contribute to the identification and inner connectedness of people with Ort/place through the deliberate and subtle incorporation of historical aspects into future use.

- Architecture and urban planning should not be solely concerned with functional, structural, technical and design issues, although they are undoubtedly important.

- An architect's work should involve the creation of a content-related milieu with a project-specific language, that enables dialogue with prospective users on a completely new level.

Form, space and materiality are the fundamentals of architecture, not in a narrow formalistic way but as the German artist and sculptor Joseph Beuys would have put it, as a material expression of the meaning, content and context of the building. The building should speak to people on a subliminal, intuitive level. Form does not exist detached from content, but as an expression of it. As already noted, it is sometimes appropriate to develop a project-specific language to express the story behind structure and material with an additional layer that might be regarded as fictional. In an ironic twist to the form follows function dictum grasped by $20^{\text {th }}$ century modernist architects, it could be said that form follows fiction!

\section{From Berlin to Mössingen}

How does this relate to the refurbishment of the Pausa Tonnenhalle? For the small town of Mössingen, the Pausa is an icon similar to the Berlin Wall for Berlin or the Frauenkirche for Dresden. The Pausa company was founded during the Weimar Republic (1919-1933) by the Jewish entrepreneurs Artur and Felix Löwen- 
stein from the village of Pausa in the Vogtland. The company was compulsorily sold to a local person, a so-called Aryan (term used by Nazis to describe a particular ancestry) textile entrepreneur following the workers' revolt against the rise of Hitler in 1933, coincidentally the only one at the time, which was supported by the Löwensteins. After the Second World War until it went bankrupt in 2004, the Pausa company earned a worldwide reputation and was the largest employer in Mössingen (Figure 4).

The way in which their Pausa was destroyed remained in the collective memory of the people of Mössingen. Jewish history and the rebellion against Hitler marked by the Deutsche Kommunistische Partei (DKP)/German Communist Party flag on the chimney of the Pausa, were collectively suppressed. After the closure of Pausa in 2004, the original deep connection, and perhaps also the love/hate relationship of the community towards its company, were followed by great bitterness and disappointment, which almost led to the demolition and extinction of the listed historic complex.

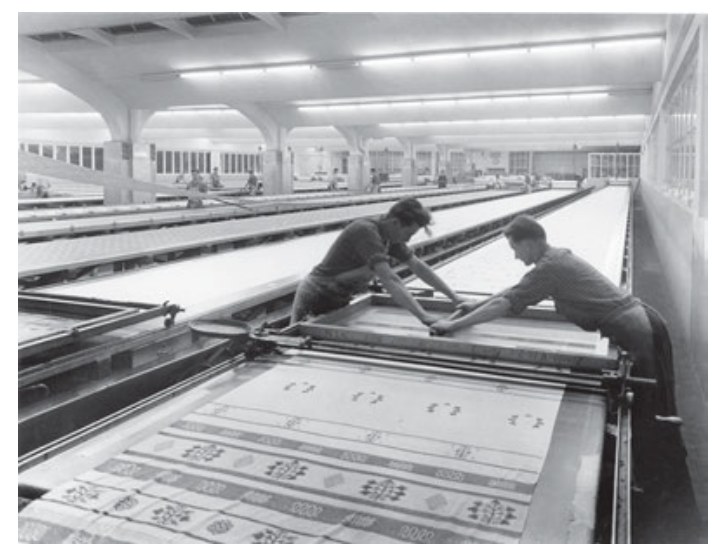

Fig. 4: Workers printing fabrics in the old factory hall. ( ) Stadt Mössingen.

While teaching at the Technical University of Dresden in the 1990s, I witnessed heated discussions about the reconstruction of the Frauenkirche. The church was destroyed by bombing during the Second World War and the ruins retained for many years as a memorial and key example of the trauma caused by the war. It became the symbol of the effort to encapsulate the enormous loss the people of Dresden experienced and from which they still are suffering.

As a visitor, or newcomer, to Dresden, the notion of a collective post-traumatic mourning and even fear was palpable and almost tangible. The Trümmersteine/rubble stones of the Frauenkirche were catalogued and neatly stored on huge shelves (Figure 5) and the Trümmerberg-Mahnmal/rubble mountain memo- 
rial became an anti-war memorial during the time of the GDR, creating a very impressive installation and a conceptually convincing image. It was, however, only the detailed reconstruction of the Frauenkirche completed in 2004 as the physical and symbolic centre of the city which brought peace to the hearts and souls of the Dresden people.

The old stones, blackened by the devastating fire, stand out in the rebuilt façade and serve as physical and conceptual reminders of the past. With the passing of time, the variation in patina will disappear, as perhaps will the trauma of loss. Dresden has successfully embraced the concept of trauma recovery, remaking the city and rebuilding community in a convincing, urbanistic and architectural way.

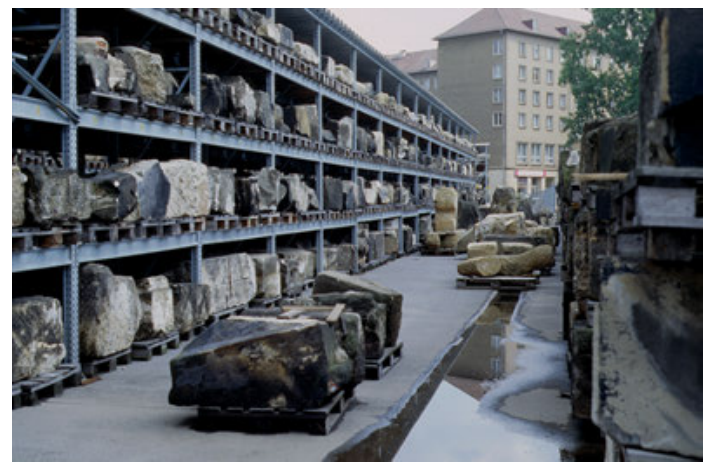

Fig. 5: Structural fragments stored in front of the ruins of the Frauenkirche in Dresden. (c) Michael B. Frank.

The same approach cannot necessarily be duplicated at a similar scale or superficially transferred to other places. Although the Pausa may be a smaller and less symbolic project, it has its specific historic context, and for the people of Mössingen, is just as important.

The Tonnenhalle/barrel-shaped printing hall has been preserved and converted through the language of architecture at several levels. In addition to the functional, constructive, technical and formal aspects, the history of the building was preserved as a distinct layer. Today, Mössingen and its people have regained their Pausa and it could be said that they have made peace with its history. The building symbolises emotional growth and development and is today a popular and important public meeting place for the city. The new city library occupies the former Tonnenhalle and is located on the renamed Löwensteinplatz ${ }^{1}$.

1 While the Pausa project was in progress, a society celebrating the history of the Pausa was founded in Mössingen by Dr. Berner of the local Heimatmuseum. It was discovered that the daughter and son of Artur and Felix Löwenstein were still alive and had been living in London and Manchester since the late 1930s following their parents' escape from Nazi Germany. The 


\section{An Outstanding Achievement}

Thanks to dedicated commitment and amazing craftsmanship of all involved, many details within the building were preserved along with evidence of past production. Clever intervention ensured that the old and new could be clearly seen side by side. The soul and spirit of the building were preserved for future generations.

The project has made a significant impact on Mössingen. People commemorate the past and reflect with pride on the history of Pausa. Pausa's achievements are celebrated and its failures and issues no longer suppressed. The Tonnenhalle conversion is not only a high-quality architectural project; it is also a first-rate example of urban renewal.

Putting into practice the thesis of SubBerlin, the Pausa complex, which had been viewed negatively because of its traumatic history, once again is connected with the city and its people in a dynamic way both on a practical and spiritual level. It makes a valuable contribution to urban renewal far beyond standard urban planning. The people of Mössingen intuitively feel new respect for the complex and express it through positive participation in its activities.

The aim of my work has always been to expose the many facets and layers of a city and of its buildings to ensure they speak to and connect with current and future generations who will identify with the specific aura of the place. Cities around the world are changing rapidly and becoming ever more indistinguishable. I would argue, perhaps a little controversially, that beneath the ubiquitous shopping malls, the unique stories, evidence and memories of the past lie buried, unheralded, unidentified and unknown.

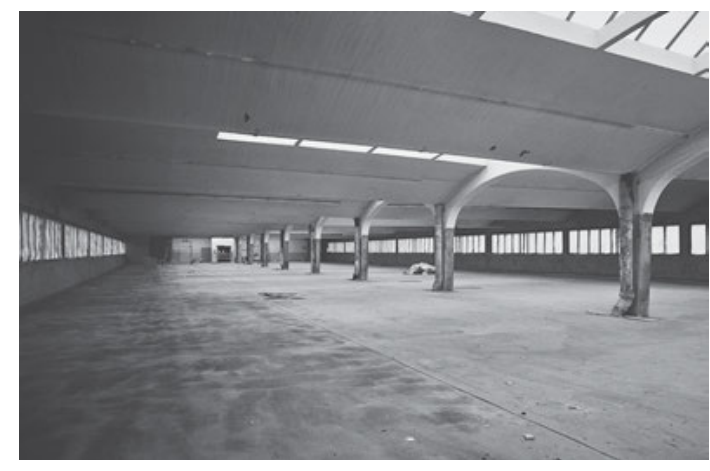

Fig. 6: The upper floor before reconstruction. (C) Michael B. Frank.

most emotional moment in the seven years I was working on the project was when the two wonderful elderly people came to the opening of the Tonnenhalle and the official renaming of the street from the name of the Aryan company leader to Löwensteinplatz in February 2011. 
An initial proposal for the construction of a Fachmarktzentrum/shopping mall with 150 parking spaces on the Pausa site would have led to the demolition of Lehmbruck's historic complex. It was successfully opposed and replaced by the current scheme.

A worldwide tendency to ignore the past leads to a loss of uniqueness and to alienation. It is generally accepted that identifying with a place and its buildings and embodied memories, both good and bad, keeps the community together and ultimately contributes to its wellbeing. It is essential to demonstrate that old buildings deemed unusable or uneconomic can be preserved and new uses found. New structures or spaces gain in value and relevance when connected respectfully with and integrated into a place, its past and its people. The new structures or spaces tell their own stories and gain in depth and power.

\section{The Design Phase}

\section{The Voids}

The five voids cut out of the Tonnenhalle do not point to the past like the thirteen holes, dug into the sand of the death strip of SubBerlin. They clearly and consciously point to the future and have clearly defined functions. The ceiling opening brings light and air into the building; the panoramic window looking out to the Swabian Alps lends distance to the view (Figure 7); the smaller bay window offers a more focused, telescopic view.

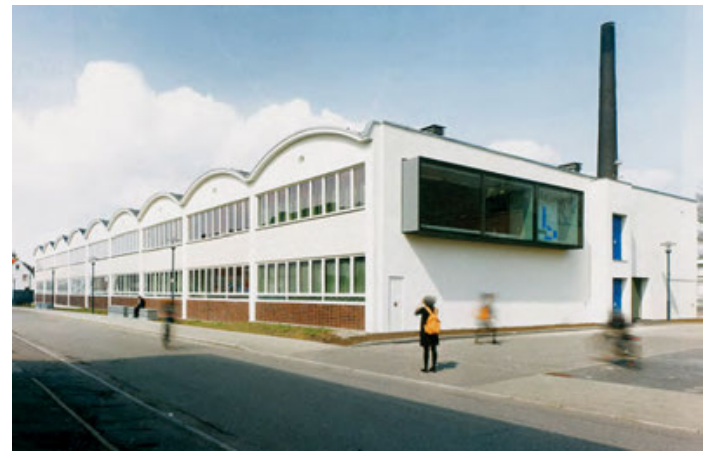

Fig. 7: Readers' bay window as a panoramic window. (C) Wolfram Janzer. 


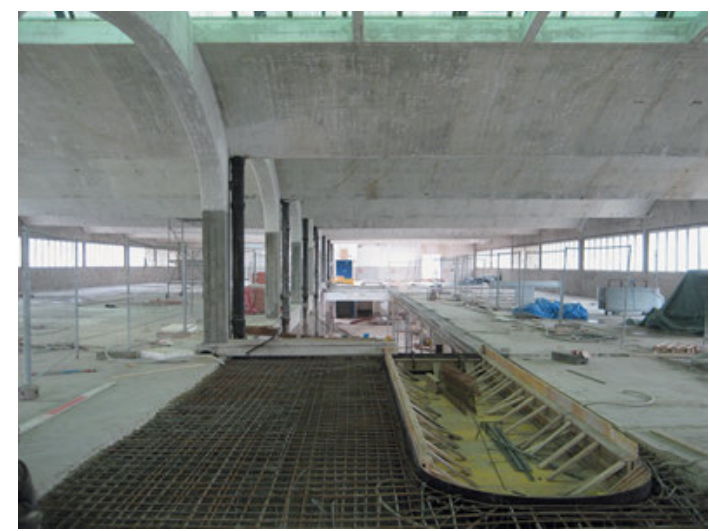

Fig. 8: The central element of the reconstruction work is a cut through the concrete ceiling. (c) Michael B. Frank.

In the SubBerlin project, the cut made through the building instantly reveals its history and metaphorically represents the urge for insight in the sense of an archaeologist or a surgeon cutting the surface to find out what lies behind. It might even be seen as a subtle reference to breaking through conventional and authoritarian constraints, not least the taste and style authority of some architecture schools! In the Tonnenhalle, the idea of the surprising and "daring cut" (Remmele 2011) made it a living, imaginable and feasible project. The cut was like the liberating, life-giving effect of a tracheotomy (Figure 8). It brought light to the ground floor and enabled the installation of a generous access ramp.

The passage of time is inexorable; it can not stand still nor is it desirable for it do so. The only constant is change and the notion of the ramp as a conveyor belt can be interpreted as representing change. The ramp in the Tonnenhalle (Figure 9) leads the visitor on a deliberately lengthy path through almost the entire $80 \mathrm{~m}$ length of the building, past visible traces of the historic production work and the open, uncovered wounds of the new intervention, the ceiling cuts. The ramp is supported by only one V-support in the centre and is located as a new access element to the library. 


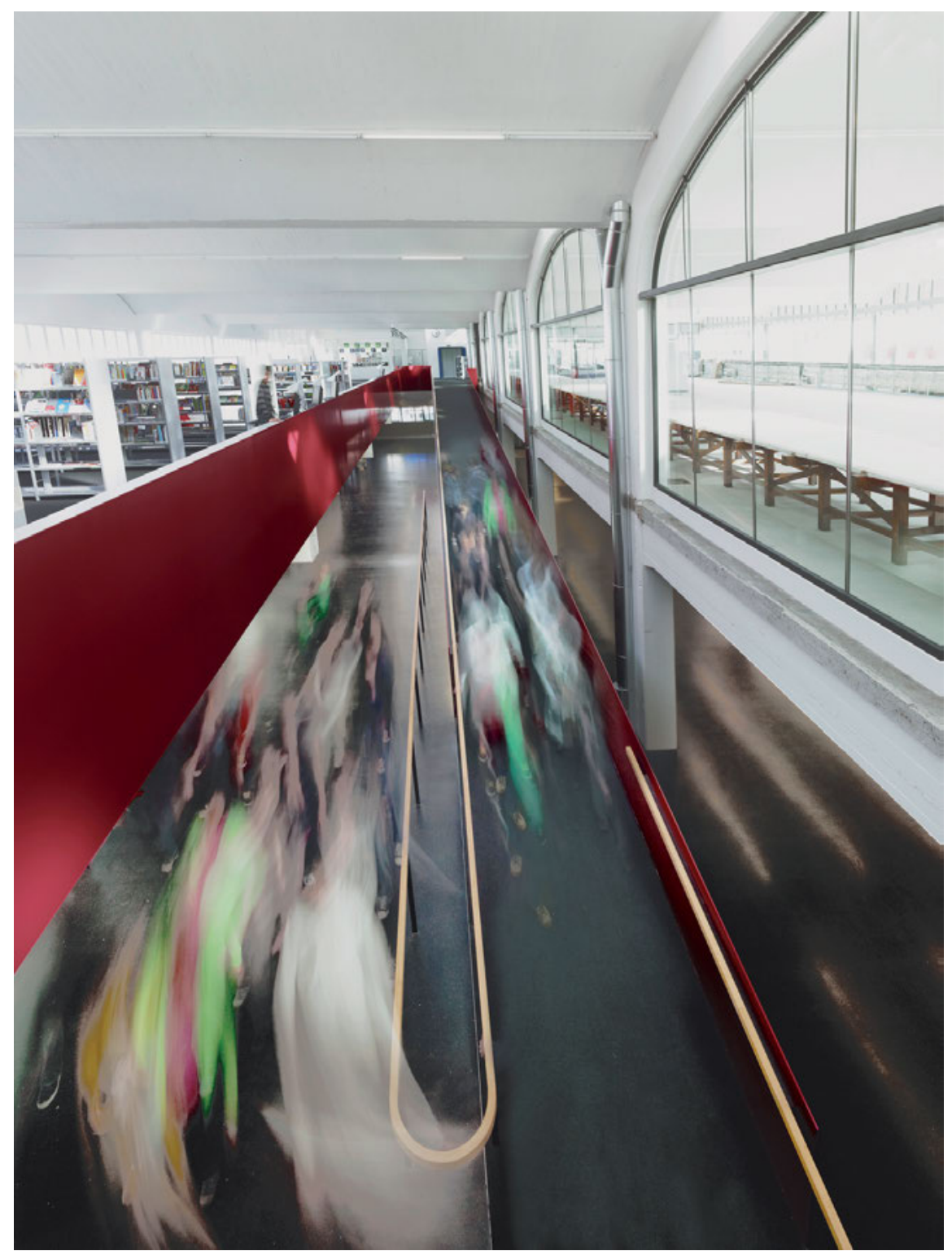

Fig. 9: In the light-flooded air space of the ceiling slit, the $38 \mathrm{~m}$ cantilevered ramp. () Wolfram Janzer. 


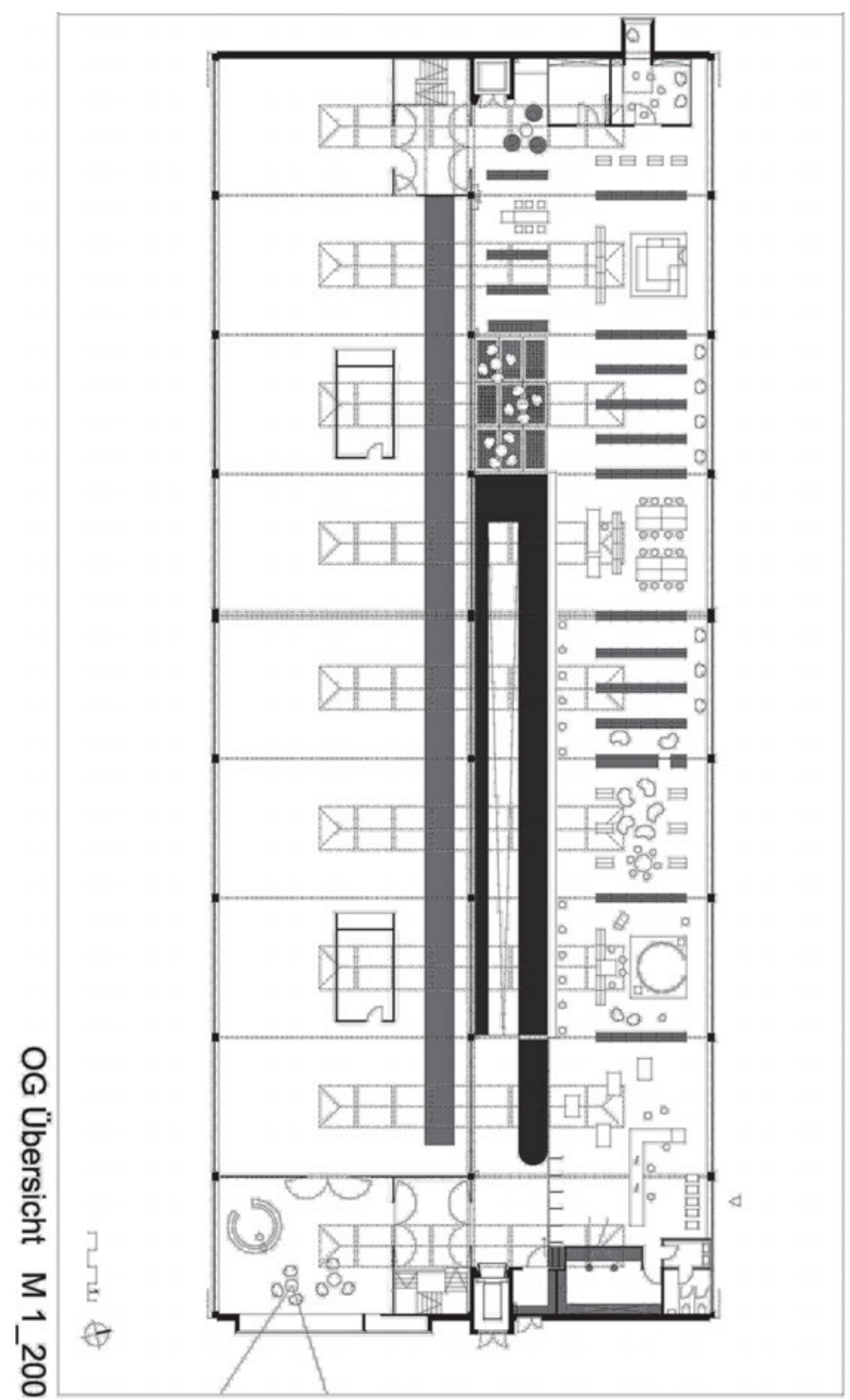

Fig. 10: The plan of the finished project. (C) baldauf architekten gmbh (Frank 2011). 
The ramp constitutes a path (Figure 10) for those who appreciate the subtlety of the design, pause to absorb and experience the newly created spaces, and stroll through time and history. The ramp connects the past with the future of the Pausa Tonnenhalle at a creative, spatial, formal but also an imaginative level.

\section{Evidence of the Past and Machine Aesthetics}

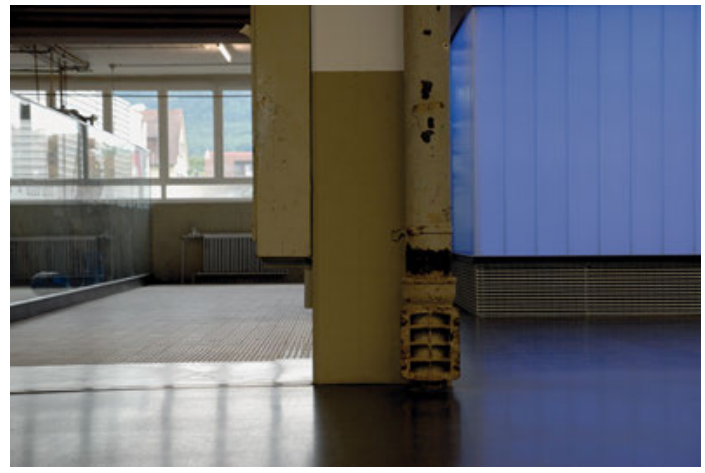

Fig. 11: Machine aesthetic and traces. () Michael B. Frank.

At SubBerlin, the emphasis on machine aesthetics is a deliberately chosen reference to the popular avant-garde architecture of Sir Richard Rogers and to the concepts of the 1960s Archigram. At the Pausa, however, it translates into the authentic effect of the old industrial atmosphere in the former industrial plant (Figure 11). To identify and preserve the remains of past industrial activity, the concept of Intarsien/inlays, was fundamental to the architectural endeavours to which almost everything else was subordinated.

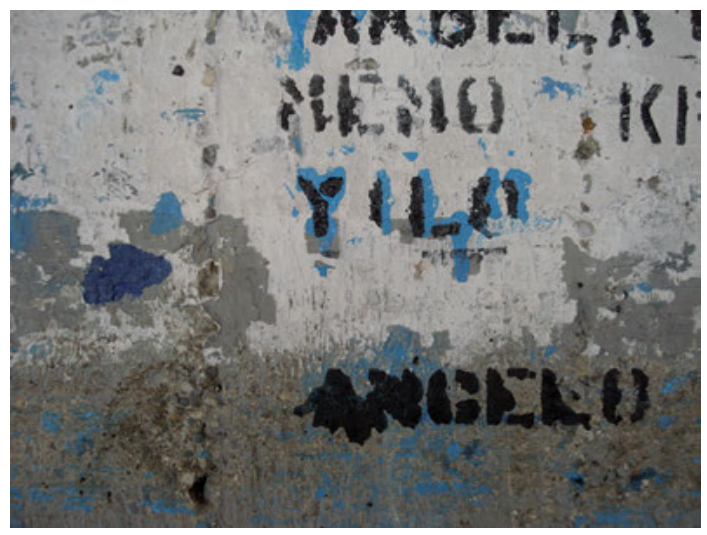

Fig. 12: The legacy of Angelo kept alive. () Michael B. Frank. 
From rough surfaces, historical structures and materials to ancient remnants of past activity, old paint spots, amusing legacies of the workers (Figure 12) and time clocks, all the way to a whole production unit, the Farbküche/dyeing room (Figure 13), much could be kept as it was. Even with all the modern requirements of technology and users, history still lives in the building. The evidence of past use, much of it apparently archaic today, occupies its proper place and tells the young and future generations about the production processes in the old Pausa complex.

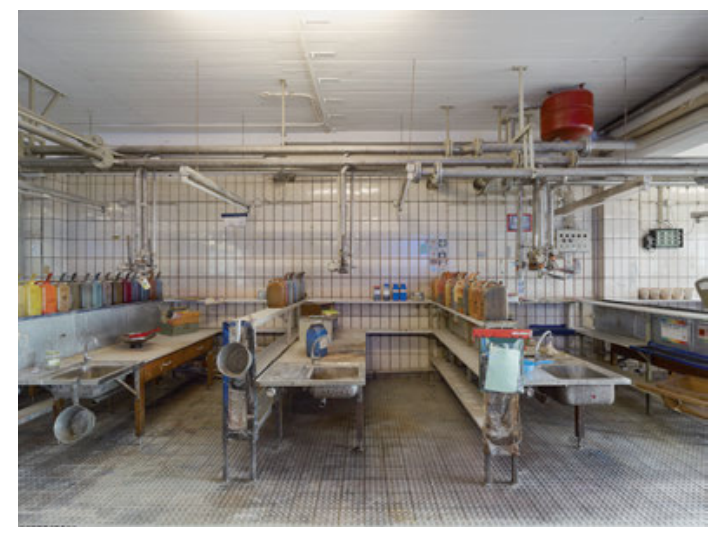

Fig. 13: The abandoned original dyeing room. () Wolfram Janzer.

The Deutsche Bauzeitung reported that "The Tonnenhalle presents itself today as a contemporary building with an industrial past, in which old and new coexist in an exciting, but always harmonious dialogue" (Remmele 2011).

Rudolf Schwarz, a German architect who designed highly regarded post-war churches sometimes using the rubble of almost totally destroyed churches, or building on their ruins, expressed a similar theory when he noted that architects should pay serious attention to existing structures, regarding them not as dead objects but enduring entities that live on amongst us. He emphasised the importance of entering into a dialogue with the original building, listening to what it has to say and responding in creative ways which imbue new life for the building (Peter and Wimmer 1998, 12) ${ }^{2}$.

2 Summarised from the original German: "Man sollte das alte Werk ganz und gar ernst nehmen, aber nicht als ein Totes, sondern als ein Lebendiges, das unter uns lebt - weiterlebt - und mit ihm eine Zwiesprache beginnen, lauschen, was es zu sagen hat, und sagen, was wir als lebendige Menschen zu antworten haben, und ihm so als einem Lebendigen ein neues Lebendiges einfügen“ (Peter and Wimmer 1998, 12). 


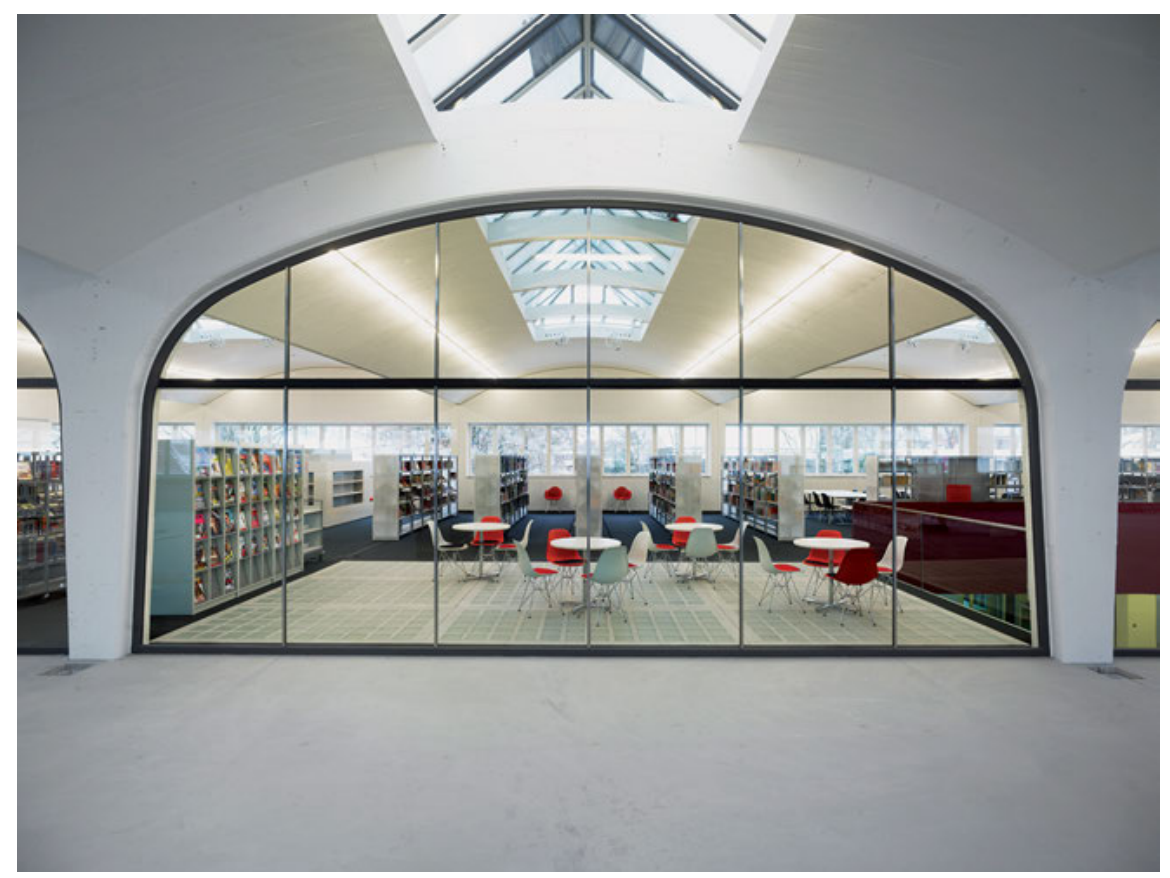

Fig. 14: The library: the fitted glass walls allow a functional division of the old production hall without destroying the spatial context. (๖ Wolfram Janzer.

\section{The Librarian's View: Something Old - Something New}

The Pausa Company was not just a factory. Many Mössingen inhabitants associate Nationalsozialismus/National Socialism/Nazism and the war with the factory. The decision to rename the square outside the library after the founders was an important political statement. The Pausa still has great importance for many inhabitants and some feel very connected to the building as becomes clear during guided tours and at exhibitions. Former Pausa employees often visit the library to look around and tell their stories.

Every day the librarians are reminded of the history of the company which was so successful in the past. Rather than finding the design of the old building an obstacle to their work, the staff have adapted their work processes to embrace the special features. Many elements of the former Pausa remain in the library which can, at first, seem a little strange but they add to the character and sense of 
history. The library retains memorabilia from the old Pausa building with display cases containing fabric samples and pictures integrated into the counter and information desk. The most striking and frequently used heritage feature is the toilet, which has been faithfully preserved (Figure 15).

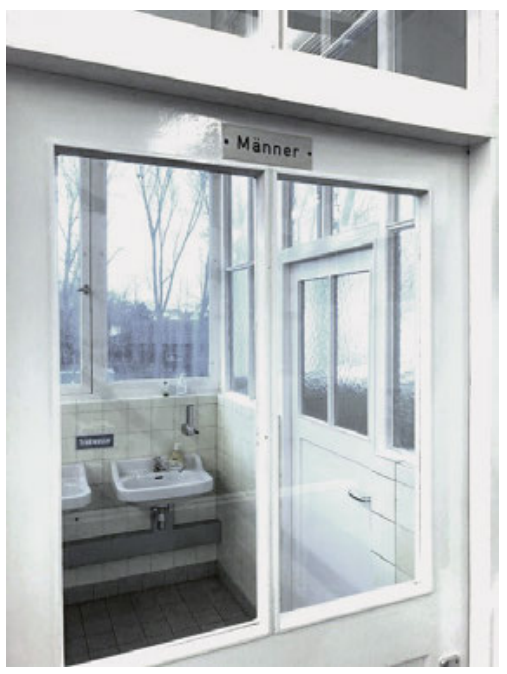

Fig. 15: The most striking and frequently used heritage feature serves today as toilet. (c) Canan Kadi.

\section{Historic Building Preservation versus User-Friendliness}

The listed building regulations for historic buildings have meant there are some restrictions on library design. An external book return box for users to drop off loans outside of opening hours was approved. Unfortunately, it was not possible to install a more modern return system because the façade is listed and no changes were permitted. The biggest disadvantage of a listed façade is, probably, the restrictions on library signage.

The windows reflect the charm of the former factory building. Unfortunately, due to their age, they are no longer completely sealed and in winter the library can be cold. In summer, conversely, the temperatures sometimes rise to 36 degrees Celsius, which does not encourage customers to linger for long. Library staff struggle with the heat resulting in a decision to introduce shorter working hours during the summer holidays. 
The former Pausa building is incredibly special. The high ceilings, the numerous windows and the fact that it is a single-storey building provide a very pleasant workplace and the interplay of modern furniture and old factory elements gives the library its very own charm (Figures 14 and 16). Accessibility and openness are highly valued by visitors and users with disabilities have easy access.

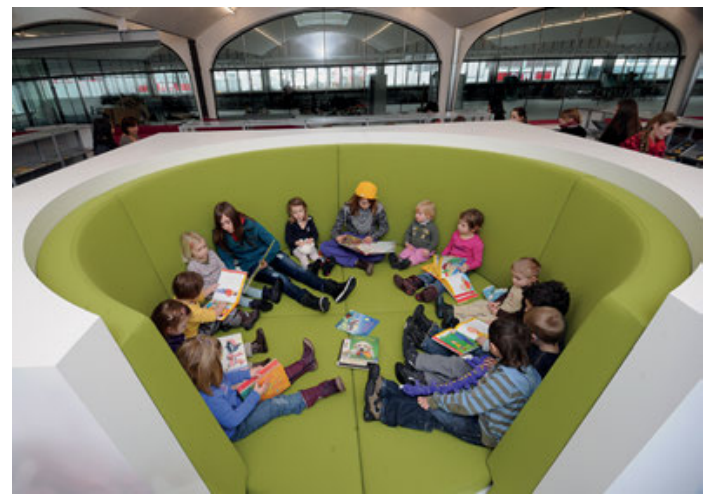

Fig. 16: An island for the children. (c) Wolfram Janzer.

\section{Conclusion}

During the entire planning and construction period, the main goal was to respect the old in the context of the new and ensure both worked together in harmony. Vestiges of the building's past life as a factory ranging from paint splashes, machinery and fittings, to entire production units, are preserved in the public areas of the barrel hall. The raw surfaces and materials create the image of the new Pausa after the conversion. The industrial character is retained with the interventions clearly indicated, a simple lighting concept and the use of a limited colour palette and range of materials (Architektenkammer Baden-Württemberg 2011; Baus 2012; Frank 2011; mbfrankarchitektur 2011). All is achieved while meeting the requirements of a modern library and its users, and complying with relevant building standards and legal regulations. Added value is provided by the special aura created by the historical remnants of the former factory. The building is lively and exciting and communicates its history as an industrial production facility to future generations. 


\section{References}

Architektenkammer Baden-Württemberg. [2011]. "Denkmalgerechte Sanierung und Umbau der PAUSA Tonnenhalle zur Stadtbücherei Mössingen.” Beispielhaftes Bauen: Auszeichnungsverfahren “Tübingen 2004-2011". https://www.akbw.de/ baukultur/beispielhaftes-bauen/datenbank-praemierte-objekte/detailansicht/objekt/ denkmalgerechte-sanierung-und-umbau-der-pausa-tonnenhalle-zur-stadtbuechereimoessingen-3674.html

Baus, Ursula. 2012. “Druckerei wird Stadtbücherei.” Bauwelt 33: 29-33. https://www.bauwelt. $\mathrm{de} / \mathrm{dl} / 791082 /$ bw_2012_33_0028-0033.pdf

Frank, Michael B. 1992. "Ein Museum für Deutsche Geschichte.” Diploma-Thesis at the Bartlett School of Architecture in London, 1990/91. Bauwelt 83, no.19/20: 1104-1105.

Frank, Michael B. 2011. "Eine Tonnenhalle von schlichter, puristischer Form und Räumlichkeit ... Die Stadtbücherei Mössingen zieht in ein denkmalgeschütztes, spätmodernes Industriegebäude." In Secondhand - aber exzellent! Bibliotheken bauen im Bestand, edited by Petra Hauke and Klaus Ulrich Werner, 214-225. Bad Honnef: Bock + Herchen. https://edoc.hu-berlin.de/handle/18452/2931

Hoffmann-Axthelm, Dieter. 1987. Wie kommt Geschichte ins Entwerfen? Aufsätze zu Architektur und Stadt. (Bauwelt Fundamente, 78). Braunschweig: Vieweg.

mbfrankarchitektur. [2011]. "Denkmalgerechte Sanierung und Neuausbau | Auszeichnung Beispielhaftes Bauen LK TÜ 2011, Pausa Mössingen - Stadtbücherei.” http://www. mb-frank-architektur.de/referenzen/architektur/denkmalgerechte-sanierung-undneuausbau-auszeichnung-beispielhaftes-bauen-lk

Remmele, Mathias. 2011. "Kühner Einschnitt: Stadtbücherei und Dienstleistungsgebäude in Mössingen.” Deutsche Bauzeitung 5: 18-25. https://www.db-bauzeitung.de/db-themen/ $\mathrm{db}$-archiv/kuehner-einschnitt/

Peter, Franz, and Franz Wimmer, eds. 1998. Von den Spuren: Interpretierender Wiederaufbau im Werk von Hans Döllgast. Salzburg: Pustet. 